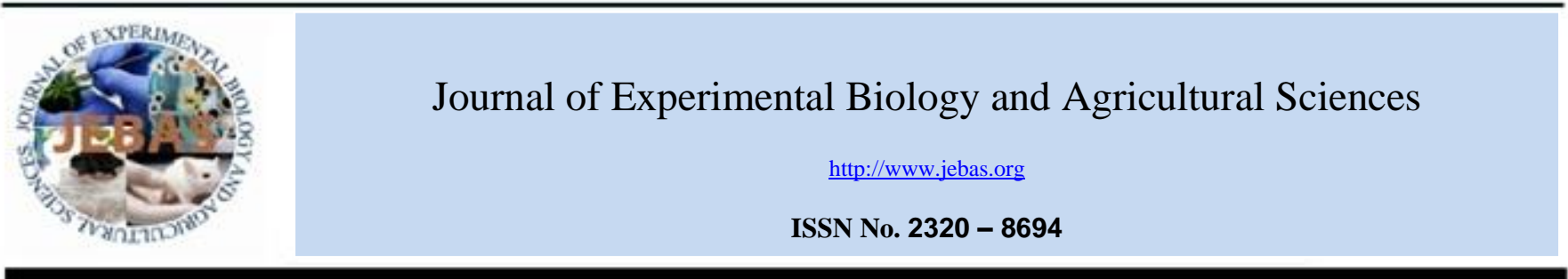

\title{
THE EFFECTIVENESS OF PROGRESSIVE MUSCLE RELAXATION AND DEEP BREATHING TECHNIQUES TOWARD STRESS SCORES OF ADOLESCENTS
}

\author{
Suyami, Devi Permata Sari*
}

Department of Nursing, Sekolah Tinggi Ilmu Kesehatan (STIKES) Muhammadiyah Klaten, Jawa Tengah, Indonesia

Received - September 25, 2020; Revision - November 16, 2020; Accepted - December 14, 2020

Available Online - December 15, 2020

DOI: http://dx.doi.org/10.18006/2020.8(Spl-2-AABAS).S336.S340

KEYWORDS
Adolescence
Stress
Progressive Muscle
Deep Breathing
Stress

\begin{abstract}
Adolescence was characterized by the adolescent identity crisis. Adolescents who experienced difficulty can be able to stress. Adolescents who experience academic stress are caused by exhaustion in learning, so many tasks, and full schedules of activities. Treatment which diminishes was of scholastic pressure thought reformist muscle unwinding and profound breathing unwinding methods. The reason for this exploration was to discover the viability of reformist muscle unwinding and procedures profound breathing unwinding toward stress scores in adolescents in the case of high school students in SMK N 1 Jogonalan, Klaten, Indonesia. During this research a quasi experimental design was used. The respondent for this investigation was the students of class X, each group has 9 participants. A random sampling technique was used for sampling. The instruments used were booklets, leaflets, and DASS. Bivariate factual test utilizing Paired ttest and Independent t-test was used for statistical analysis. The stress score was 19.00 before being given progressive muscle relaxation technique and after given progressive muscle relaxation technique, it was reported 16.33. Further, the stress score was 16.67 before the deep breathing relaxation was given and this was 13.78 after the technique of deep breathing relaxation was given. There was a difference in the viability of reformist muscle unwinding with profound breathing unwinding procedures in a pressure score that appeared p-value $>0.05$.
\end{abstract}

* Corresponding author

E-mail: devisari_07@yahoo.com (Devi Permata Sari)

Peer review under responsibility of Journal of Experimental Biology and Agricultural Sciences.

Production and Hosting by Horizon Publisher India [HPI] (http://www.horizonpublisherindia.in/).

All rights reserved.
All the articles published by Journal of Experimental Biology and Agricultural Sciences are licensed under a Creative Commons Attribution-NonCommercial 4.0 International License Based on a work at www.jebas.org.

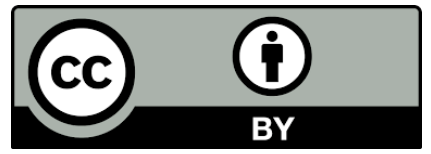




\section{Introduction}

Teenagers are those who try to break away from dependence on parents and will start looking for their identity. The stages of adolescent development include early adolescence, middle adolescence, and late adolescence (Soetjiningsih, 2010; Dewi \& Lintang, 2015). According to the World Health Organization (2014), a group of teenagers amounting to 1.2 billion or $18 \%$ of the world's population. The Population Census of 2010 mentions that the number of 10-19 year age groups in Indonesia as many as 43.5 million or around $18 \%$ of the total population.

Adolescence is synonymous with "rebellion" or storm and stress. This was caused by the many shocks and quite radical changes from the previous period. Changes that occur in adolescence include hormonal changes, psychological changes, and physical changes (Pieter, 2010). It is characterized by the emergence of characteristics of adolescents called "identity crisis". Many individuals are unable to achieve happiness in life because of an inability to adapt. This results in underprivileged teenagers in mastering and controlling emotions. This condition makes teenagers always experience storm and stress (Pieter, 2010).

Adolescents who attend Vocational High Schools (SMK) experienced several changes, namely having a lot of material that must be learned in a short time, many tasks, KKM targets (Minimum Completion Criteria) that must be exceeded, demands for academic achievement that increases both from parents, teacher and peers, pressure to rise in class and desire to continue careers (Ilmi \& Ertilkhtiarini, 2017). Vocational teenagers who experience academic stress can also be caused by fatigue in learning, the task is so much less time to rest themselves (schedule of solid activities), and anxiety facing the exam (Suyono et al., 2016). Teenagers at this time will experience a variety of life dynamics that often cause psychological stress that will lead to stress (Muhith, 2011; Radityo, 2017).

Regional Health Research (2013) suggested that the prevalence of people suffering from emotional mental disorders at age 15 and overreached around 14 million in Indonesia. The prevalence of stress events in Central Java is $4.7 \%$ of the total population of Central Java (Riskesdas, 2013). One of the adverse effects of such depression is suicide and annually $5-10 \%$ of teens committed suicide due to excess stress (Astuti et al., 2017; Prasanna \& Sushama, 2017).

If stress is not treated immediately, it can have severe physiological, psychological, and behavioral impacts. Stress in vocational high school adolescents originating from academic factors can lead to distortions in students' minds and affect physical, emotional, behavioral, and disruptive learning processes (reaction to stressors) and even decreased learning achievement
(Suyono et al., 2016). Overcoming stress can be with drugs and nondrug. Drug therapy is in the form of anxiolytic and antidepressant drugs. Non-pharmacological therapy can be done in various ways such as psychotherapy, psych religious therapy, psychosocial therapy, counseling, and relaxation therapy (Fitri \& Rakhmawatie, 2012). One of the efforts to reduce academic stress in vocational youth is through relaxation techniques. Feelings that are calm and comfortable will sustain the birth of positive, normal, and controlled thinking and behavior (Suyono et al., 2016).

This progressive muscle relaxation (PMR) begins by focusing on the activity of the muscles, identify tense muscles, and then relaxing to reduce tension (Taufik et al., 2013). The ultimate goal of relaxation techniques is to resist the formation of stress responses, especially in the nervous system and hormones (Ratna, 2010; Mohammad \& Mohammad, 2014). PMR is a nonpharmacological therapy that has no side effects and is easy to do (Furqan, 2017).

Besides the progressive muscle relaxation technique, other therapies are deep breathing relaxation techniques. This technique starts with deep breathing, slow breathing (holding inspiration to the fullest) exhaling slowly (Untari \& dan Rohmawati, 2014). This therapy can be done independently, is relatively easy to do, and does not require a long time so it can be done in various places (Richard \& Noritasari, 2015). The current study was carried out to examine the impact of PMR techniques and deep breathing relaxation techniques on stress scores in adolescents

\section{Materials and Methods}

The examination configuration utilized was the Quasi trial plan, with the pretest and posttest nonequivalent benchmark group plan, this plan was nearly equivalent to the pre and post test control bunch plan, just in this plan the exploratory gathering and the benchmark group were not haphazardly chosen (Setiawati, 2015 ). The respondents selected for this study were class $\mathrm{X}$ students consisting of 3 classes in SMK N 1 Jogonalan with a total of 108 students. The random sampling method was used in this research. The required samples were 9 respondents for the progressive muscle relaxation group and 9 respondents for the deep breathing relaxation group.

The inclusion criteria were adolescents aged 15-16 years, willing to become participants, adolescents who had a screening stress score of $\geq 14-25$. Exclusion criteria used for this study were adolescents who received other therapies, adolescents who were sick, adolescents who did not attend school, adolescents who did not participate in activities until completion.

The instrument in this study is a booklet which contains the preparation and procedure of progressive muscle relaxation 
measures, a leaflet that contains understanding, benefits, indications, preparation and procedures for deep breathing relaxation, the DASS Stress Scale (Depression Anxiety Stress Scale). This research was conducted on 7-11 May 2018; before starting the study the booklets of progressive muscle relaxation groups and leaflets for deep breathing relaxation were distributed to the researcher's groups so that they could study before giving relaxation treatment. The study was carried out during the recess period for a group of relaxation, the deep breath for 15 minutes every time the exercise with a 2 -second pause every repetition in the room, while for doing a progressive muscle relaxation technique 15 minutes indoors activities were given. This study uses a matched t-test factual test and autonomous t-test. This study using a significant level of 0.05 .

\section{Results}

Results mentioned in table 1 represent the mean pre test stress score in the progressive muscle relaxation group 15-24.The mean posttest stress score for progressive muscle relaxation group $8-21$. Whereas the mean pretest stress score in the breath relaxation group was 15-19. Whereas the posttest stress score in the group breathes relaxation in between 11-15.

Results presented in table 2 revealed that the normal pressure score before being given progressive muscle relaxation technique is 19.00 . The average stress score after being given a progressive muscle relaxation technique is 16.33 . The results of the p-value were obtained 0.037 ( $\mathrm{p}<0.05)$ so it tends to be reasoned that there is an impact of reformist muscle unwinding methods on pressure scores in teenagers in SMK N 1 Jogonalan.

Results given in table 3 revealed that the average stress score before giving deep breathing relaxation techniques was 16.67 while the average stress score after deep breathing relaxation technique was 13.78. The results of the $p$-value were obtained 0.011 ( $\mathrm{p}<0.05)$ so that it tends to be reasoned that there is an impact of profound breathing unwinding procedures on pressure scores in teenagers in SMK N 1 Jogonalan.

Table 4 shows that $\mathrm{p}$ esteem is 0.106 ( $\mathrm{p}$ value $>0.05$ ) so it tends to be closed that there is no distinction in viability between gatherings of reformist muscle unwinding procedures and profound breathing unwinding methods.
Table 1 the Mean of Stress Score

Score Stress of PRM Group

\begin{tabular}{|ccccc|}
\hline Pretest & Min & Maks & Mean & SD \\
\hline & 15 & 24 & 19.00 & 2.872 \\
\hline Posttest & 8 & 21 & 16.33 & 4.183 \\
\hline & Score Stress of Deep breathing & Group & \\
\hline Pretest & Min & Maks & Mean & SD \\
\hline & 15 & 19 & 16.67 & 1.500 \\
\hline Posttest & 11 & 15 & 13.78 & 1.394 \\
\hline
\end{tabular}

Table 2 Stress Scores before and After Being Given Progressive Muscle Relaxation Techniques

\begin{tabular}{cccccc}
$\begin{array}{c}\text { Score of } \\
\text { stress }\end{array}$ & Group & $N$ & Mean & Deviation Std & $P$ value \\
\hline Pretest & PRM & 9 & 19.00 & 2.872 & 0.037 \\
\hline Posttest & & 9 & 16.33 & 4.183 & \\
\hline
\end{tabular}

Table 3 Stress Scores Before and After Being Given Deep Breathing Techniques

\begin{tabular}{clcccc}
$\begin{array}{c}\text { Score of } \\
\text { stress }\end{array}$ & Group & $N$ & Mean & $\begin{array}{c}\text { Deviation } \\
\text { Std }\end{array}$ & $\begin{array}{c}P \\
\text { value }\end{array}$ \\
\multirow{2}{*}{ Pretest } & $\begin{array}{c}\text { Deep Breathing } \\
\text { Techniques }\end{array}$ & 9 & 16.67 & 1.500 & 0.011 \\
\hline Posttest & & 9 & 13.78 & 1.394 & \\
\hline
\end{tabular}

Table 4 Thee distinction of reformist muscle unwinding strategies and profound breathing unwinding towards the pressure of scores

\begin{tabular}{|cccccc|} 
Score of stress & Groups & N & Mean & SD & P value \\
\hline PRM & 9 & 11.50 & 103.60 & 0.106 \\
\hline Deep Breathing & 9 & 7.50 & 67.50 & \\
\hline
\end{tabular}

\section{Discussion}

\subsection{The Impact of PMR techniques on stress score}

The results showed that the respondents who have given PMR techniques the average value of stress scores before treatment was 19.00 , while the average stress score after being given progressive muscle relaxation techniques decreased to 16.33 . The results of the $\mathrm{p}$-value were obtained 0.037 ( $\mathrm{p}<0.05$ ) so it is very well understood that there is an impact of reformist muscle unwinding procedures on pressure scores in young people in SMK N 1 Jogonalan. 
Research conducted by Barseli et al. (2017) shows that reformist muscle unwinding is successful in lessening the pressure of education among teenagers in school. Resti's research (2014) found that reformist muscle unwinding strategies can help decrease feelings of anxiety and stress side effects.

Progressive muscle relaxation techniques are based on the body reacting to anxiety with the occurrence of muscle tension. When individuals experience tension, what works is the sympathetic nervous system and when relaxed, the parasympathetic nervous system works.

Physiologically this exercise will reverse the impact of stress which includes the parasympathetic part of the central nervous system (Furqan, 2017). Muscle relaxation progressively slows down sympathetic nerve activity, causing the body's dysregulated hormones to decrease in number. The parasympathetic nervous system, which functions against the sympathetic nerves, slows down the activity of organs in the body.

The impact of decreased sympathetic nerve activity is decreased heart rate, slower breathing rhythm, decreased blood pressure, diminished muscle pressure, diminished metabolic rate, and restrained the creation of stress-causing hormones. As the levels of stress hormones drop, the whole body begins to function better. The energy available can be used for healing, restoration, and rejuvenation (Furqan, 2017). Thus relaxation can suppress reciprocal tension, resulting in counter-conditioning, and individuals will feel more relaxed (Furqan, 2017)

\subsection{Effect of Deep Breathing Techniques on Stress Score}

The results of the study revealed that the respondents who were given deep breathing relaxation techniques with an average value of stress scores before treatment was 16.67 , while the average stress score after being given deep breathing relaxation techniques decreased to 13.78. The consequences of the $\mathrm{p}$ esteem acquired were $0.011(p<0.05)$ so it tends to be presumed that there was an impact of profound breathing unwinding strategies on pressure scores in youths in SMK N 1 Jogonalan. Research conducted by Suyono et al. (2016) demonstrated a diminishing in the degree of scholastic pressure before the test after getting unwinding methods.

Deep breathing therapy will respond to increasing baroreceptor activity and can reduce sympathetic nerve discharge and systemic vasodilation. Deep breath therapy for 15 minutes (100 times deep breathing) can animate the body to deliver endogenous narcotics to be specific endorphin and encephalin which functions as a natural tranquilizer produced by the body, the release of the natural tranquilizer lasts about 3 minutes then it can be felt that stress, feeling depressed reduced. When stress and other symptoms make the nervous system unbalanced, this breath relaxation technique can bring back to a balanced state by producing relaxation responses (Dharma, 2011; Richard \&Noritasari, 2015)
4.3. The viability contrast of reformist muscle unwinding strategies and profound breathing unwinding towards the pressure of scores

The difference in mean stress scores from X1-X5 in the progressive muscle relaxation group was 11.50 while the deep breath relaxation group had an average of 7.50. The consequences of the examination test acquired $\mathrm{p}$ estimation of 0.106 ( $\mathrm{p}$ value> 0.05 ) so it tends to be reasoned that there is no distinction in effectiveness between groups of progressive muscle relaxation techniques and deep breathing relaxation techniques.

In light of the consequences of the investigation, Debora (2011) found that there was no huge distinction between the reformist muscle unwinding gathering and the full breath unwinding gathering. This shows that reformist muscle unwinding strategies and deep breathing relaxation techniques are relaxation nonpharmacological therapies that both can be used in stress reduction (Fitri \& Rakhmawatie, 2012). The results of the study showed that the respondents who were given deep breathing relaxation techniques with an average.

\section{Conclusion}

Results of the study can be concluded that there is an impact of reformist muscle unwinding techniques and deep breathing relaxation techniques on stress scores in adolescents at SMK N 1 Jogonalan with $\mathrm{p}$ value $(\mathrm{p}<0.05)$. The results of differences in the viability of reformist muscle unwinding strategies and full breath unwinding on stress scores indicate that the $\mathrm{p}$ value is $0.106(\mathrm{p}$ value> 0.05) so it may be presumed that there is no distinction in effectiveness between the groups of progressive muscle relaxation techniques and deep breath relaxation techniques

\section{Conflict of Interest}

Authors would hereby like to declare that there is no conflict of interests that could possibly arise.

\section{References}

Astuti RT, Amin MK, Purborini N (2017) Efektifitas Metode Hipnoterapi Lima Jari (HP Majar) Terhadap Tingkat Stres Akademik Remaja Di Smk Muhammadiyah 2 Kabupaten Magelang. Journal of Holistic Nursing Science 4(1): 1-9. Retrieved from http://journal.ummgl.ac.id/index.php/nursing/article/view/1110.

Barseli M, Ifdil I, Nikmarijal N, (2017) Konsep Stres Akademik Siswa. Jurnal Konseling dan Pendidikan 5(3): 143-148. DOI: https://doi.org/10.29210/119800.

Debora DE (2011) The Measurement of Reability, Vadility, Items Analysisang Normative Data of Depression Anxiety Stress Scale 
(DASS). Thesis submitted to the Fakultas Psikologi Universitas Indonesia, Depok.

Dewi RC, Lintang A(2015) Teori \& Konsep Tumbuh Kembang Bayi, Toddler, Anakdan Usia Remaja.[ Theories \& Concepts of Growing Babies, Toddlers, Children and Adolescents.] Yogyakarta: NuhaMedika. ISBN: 978-602-1547-72-4.

Dharma KK (2011) Metodologi Penelitian Keperawatan [Nursing Research Methodology]. Jakarta: CV. Trans Info Medika.

Fitri R \& Rakhmawatie (2012) PerbedaanKejadianStres Antara Remaja Putra danPutridenganObesitas di SMA Negeri 1 Wonosari, Klaten.[Differences in Stress Events Between Young Men and Women with Obesity at SMA Negeri 1 Wonosari, Klaten]. Fakultas Kedokteran Universitas Muhammadiyah Semarang.

Furqan (2017) Pengaruh Terapi Relaksasi Progresifterhadap Strespada Remaja Penghuni Lembaga Pemasyarakatan Kota Samarinda [Effect of Progressive Relaxation Therapy on Stress on Adolescents in Samarinda City Penitentiary]. ISSN.2477-2674.

Ilmi ZM, Ertilkhtiarini D (2017) Pengaruh Relaksasi Otot Progresif Terhadap Tingkat Stres Narapidana Wanita di LapasKelas IIA Jember [ Effect of Progressive Muscle Relaxation on Stress Levels of Female Prisoners in Class IIA Jember Prison.].

Mohammad A, Mohammad A (2014) Psikologi Remaja [Adolescent Psychology]. Jakarta: PT. Bumi Aksara.

Muhith N (2011) Dasar-Dasar Keperawatan Jiwa [basic of mental health nursing]. Jakarta: Salemba Medika.ISBN: 978602-8570-61-9.

Pieter N (2010)Pengantar Psikologidalam Keperawatan [Introduction to Psychology in Nursing]. Jakarta. Prenada Media Group. ISBN: 978-602-8730-47-7.

Prasanna M, Sushama V (2017) Efektivitas Relaksasi Otak Progresif Jacobson (JPMR) pada Stres Pendidikan di kalanganRemaja di Sekolah. Jurnal Pendidikan Keperawatan Internasional.

Radityo C (2017) Pengaruh Coping With Stress terhadap Stres Siswa dan Stres Siswa terhadap Prestasi Akademik Ditinjau dari
Jenis Kelamin Siswa SMP Bentara Wacana Muntilan. Magister Sains Psikologi Program Pascasarjana UKSW. Available at http://repository.uksw.edu/handle/123456789/13227 access on 29th April, 2020.

Ratna A (2010) Kesehatan Remaja: Problem dan Solusinya.Jakarta: Salemba Medika. Available at http://perpustakaan.kemenkopmk.go.id/perpus/perpus/index.php?p =show_detail\&id=4609 access on $29^{\text {th }}$ April 2020.

Richard SD, Noritasari FN (2015) Potensi Relaksasi Napas Dalam Menurunkan Premenstruation Syndrome pada Remaja Putri. Jurnal Penelitian Keperawatan 1(1): 43-52. DOI: https://doi.org/10.32660/jurnal.v1i1.179.

Riskesdas (2013) RIskesdas Results 2013. Jakarta: Badan Penelitidan Pengembangan Kesehatan Kementrian RI.

Setiawati SE (2015) Pengaruh Stres Terhadap Siklus Menstruasipada Remaja. Medical Journal Of Lampung University 4(1): 94-98

Soetjiningsih (2010) Bahan Ajar: Tumbuh Kembang Remajadan Permasalahannya. [Teaching Materials: Youth Growth and Problem]Jakarta: SagungSeto.

Suyono S, Triyono T, Handarini DM (2016) Keefektifan Teknik Relaksasiuntuk Menurunkan Stres Akademik Siswa SMA. Jurnal Pendidikan Humaniora 4(2): 115-120.

Taufik T, Ifdil I, Ardi Z (2013) Kondisi Stres Akademik Siswa SMA Negeri di Kota Padang. Jurnal Konselingdan Pendidikan 1(2): 143-150. DOI : https://doi.org/10.29210/12200.

Untari I, dan Rohmawati (2014) Faktor-Faktor Yang Mempengaruhi Kecemasan Pada Usia Pertengahan Dalam Menghadapi Proses Menua (Aging Process) Di Kelurahan Jogosetran Kecamatan Kalikotes Klaten. Jurnal Keperawatan 1(2): $83-90$.

World Health Organization (2014) World Health Statistics. Tersediadalam: Available at http://apps.who.int/iris/bitstream/10665/112738/1/978[diakses padatanggal 8 Maret 2018]. 